\title{
HIV-1 REVERSE TRANSCRIPTASE AND PROTEASE ASSAY OF METHANOLIC EXTRACTS OF ADANSONIA DIGITATA L.
}

\author{
AMRISH SHARMA ${ }^{a}$, VINOD RANGARI ${ }^{*}$ \\ aFaculty of Pharmaceutical Sciences, Jodhpur National University, Jodhpur 342003 (RAJ), India, bDepartment of Pharmacognosy, Institute \\ of Pharmaceutical Sciences, Guru Ghasidas University, Bilaspur 495009 (CG), India \\ Email: dr.rangarivinod@gmail.com
}

Received: 29 Apr 2016 Revised and Accepted: 22 Jul 2016

\begin{abstract}
Objective: Anti-HIV activity studies of methanolic extracts of Adansonia digitata L. leaves, root bark and fruit pulp.

Methods: Methanolic extracts of $A$. digitata were tested for HIV enzyme inhibitory activity against HIV-1 reverse transcriptase (RT) and HIV-1 protease (PR). HIV-1 RT assay was performed using non-radioactive HIV-RT colorimetric ELISA kit while the HIV-1 PR assay was performed using a fluorogenic octapeptide substrate, HIV-FRET (fluorescence resonance energy transfer) and a recombinant HIV-1 protease solution (AnaSpec Inc., USA).
\end{abstract}

Results: The percentage inhibition of controls and A. digitata leaves, root bark and fruit pulp extracts were calculated relative to uninhibited HIV-1 RT and PR in 2\% DMSO. The results of the HIV-1 RT assay indicated $26.5 \%$ inhibition by root bark extract ( $50 \mu \mathrm{g} / \mathrm{ml})$ and $12.2 \%$ inhibition by leaf extract while the fruit pulp extract $(100 \mu \mathrm{g} / \mathrm{ml})$ has shown only $5.9 \%$ inhibition as compared to standard Nevirapine (100 nM) $27.5 \%$ inhibition.

In the case of HIV-protease assay, leaf extract and fruit pulp extract (50 $\mu \mathrm{g} / \mathrm{ml})$ has shown quite high inhibition ( $\geq 50 \%$ ) to the extent of $75 \%$ and $74 \%$ respectively which is very significant. The root bark extract has shown 35\% inhibition.

Conclusion: Methanolic extract of the leaves, root bark and fruit pulp of A. digitata has shown low anti-HIV-1 RT but significant PR activity. HIV-1 RT activity of root bark extract and HIV-1 PR activity of fruit pulp extract indicates the potential of the plant as an anti-HIV agent.

Keywords: HIV, Adansonia digitata L, Reverse transcriptase, Protease

(C) 2016 The Authors. Published by Innovare Academic Sciences Pvt Ltd. This is an open access article under the CC BY license (http://creativecommons. org/licenses/by/4. 0/) DOI: http://dx.doi.org/10.22159/ijpps.2016v8i9.12485

\section{INTRODUCTION}

India, with a population of over one billion, is experiencing a rapid and extensive spread of HIV. According to the 2012 report, the estimated number of people living with HIV/AIDS in India was 2.089 million in 2011. The adult (15-49 age-group) HIV prevalence at national level has continued its steady decline from estimated level of $0.41 \%$ in 2001 to $0.27 \%$ in 2011 . But still, India is estimated to have the third-highest number of people living with HIV/AIDS, after South Africa and Nigeria [1].

There are two related but distinct types of HIV: HIV-1 and HIV-2 [2]. HIV-1 is the most pathogenic and causes over $99 \%$ of HIV infections [3]. Various studies carried out in different parts of India highlights the fact that HIV-1 subtype C is the most prevalent subtype in India [4]. India initiated HIV-prevention activities in the very early stages of the epidemic and committed to prevention efforts. The National AIDS Control Organization [5] was constituted in 1986 and the National AIDS Control Program launched a year later. To enhance RandD in this area, NACO identifies and promotes Indian academic institutions that conduct epidemiological and operational research for the treatment of HIV/AIDS, including research on indigenous systems of medicine such as Ayurveda and Siddha. Natural products provide a large reservoir for the screening of anti-HIV agents with novel structure and antiviral mechanism because of their structural diversity. A variety of natural products has been found to inhibit unique enzymes and proteins crucial to the life cycle of HIV. The most efficient interventions are at the stages of the reverse transcription process, virus entry, integration of viral DNA into the host genome and protease inhibition [6, 7] However mechanism of anti-HIV activities of many more natural products is unknown. In India, traditional medicine is used to meet the primary health care need and to treat AIDS patients $[8,9]$. Screening of plants worldwide based on ethnopharmacological data to isolate the active constituents from plants for preventing transmission of HIV-AIDS patients increases the potential of finding novel phytoconstituents present in them [10-13].
Many compounds with anti-HIV-1 effect have been screened out from natural products and discovered to inhibit HIV at nearly all stages of viral life cycle [14]. They include alkaloids, sulphated polysaccharides, polyphenolics, flavonoids, coumarins, phenolics, tannins, triterpenes, lectins, phloroglucinols, lactones, iridoids, depsidones, O-caffeoyl derivatives, lignans, and ribosome inactivating proteins, saponins, xanthones, naphthodianthrones, photosensitisers, phospholipids, quinines and peptides [15-18].

Adansonia digitata L. family, Bombaceae, is known by various names such as Baobab and Lemonade tree. It is endemic to Africa. In India, it grows naturally in Mandu region of Madhya Pradesh. It is very common in Andhra Pradesh and also cultivated in Uttar Pradesh, Bihar, Tamil Nadu and Maharashtra [19]. It is one of the largest and reportedly longest living species (6000 y) of the world [20,21].

A variety of phytochemicals constituents such as terpenoids, flavonoids, sterols, vitamins, amino acids, carbohydrates, and lipids [21] have been reported from A. digitata. The different plant parts are widely used as food, medicine, clothing and shelter. In folk medicine it is used as antipyretic, febrifuge, astringent in diarrhoea and dysentery, also as a substitute for cinchona in various systems of medicine [22]. The pith of the fruit contains high levels of ascorbic acid (vitamin C), tartaric acid, and citric acid and is used in producing a refreshing drink. Seeds are eaten fresh or dried. They can also be ground into a powder and used as a substitute for coffee. The leaves are said to be rich in vitamin $C$, sugars, potassium tartrate, and calcium. The leaves are freshly cooked as a vegetable or dried and crushed for later use by local people $[23,24]$. The leaves are used medicinally against fever by reducing sweating and as an astringent by tightening mucous membranes thus reducing mucous secretions. In West Africa, the leaves and bark are used for treating urinary disorders and diarrhoea. Young roots are cooked and eaten [24-26]. Antibacterial and anti-Trypanosome activities have also been indicated by the plant extracts $[27,28]$. Toxicological and pharmacological studies such as anti-inflammatory, analgesic, antipyretic, antibacterial and antiviral activities of the various plant 
parts of $A$. digitata have also been reported [29]. Root bark and leaf extract of $A$. digitata have shown significant antiviral activity against Herpes simplex, Sindibis and Poliovirus [30]. This has led to the current study to investigate the potential of various plant parts of $A$. digitata to inhibit HIV-1 enzymes.

\section{MATERIALS AND METHODS}

\section{Plant collection and authentication}

Fresh leaves, fruits and root bark of A. digitata L. were collected from Mandu, Madhya Pradesh, India, in the month of September 2010. The collected plant was authenticated by Dr. Pramod Patil, Professor, Department of Botany, M. L. B. Girls Post Graduate College, Bhopal, India. Voucher specimen 00919 has been deposited in their laboratory for future reference.

\section{Extraction}

The plant material was washed well with water to separate the adhering soil material and dried in the shade. Dried leaves, fruit pulp and bark were comminuted to form a coarse powder. Dried powdered leaves, fruit pulp and bark (500 g each) were extracted with petroleum ether $\left(60-80^{\circ}\right)$ for $24 \mathrm{~h}$ to remove fatty substances. Defatted dried marc was further extracted with methanol. All the extracts obtained were evaporated to dryness under vacuum in a rotary evaporator at $40{ }^{\circ} \mathrm{C}$. All the extracts were subjected to preliminary phytochemical screening to detect various plant constituents.

\section{Analytical studies}

Fifty milligrams of the residue extract was dissolved in $5 \mathrm{ml}$ methanol in a volumetric flask, filtered and made up the volume up to $5 \mathrm{ml}$ for each sample.

HPTLC was carried out on silica gel 60 F254 precoated aluminium plates $0.2 \mathrm{~mm}$ thickness, Merck India Limited Mumbai. An Applicator from Camag Linomat-5 (Camag Switzerland: 140443) was used for band application and photo documentation unit (Camag Reprostar-3: 140604) was used for documentation of chromatographic fingerprints. The mobile phase used for leaf and fruit pulp extract was toluene: ethyl acetate: diethylamine (7:3:0.5), whereas for root bark extract it was toluene: ethyl acetate (9:1). The HPTLC plates were developed over a distance of $9 \mathrm{~cm}$ in a saturated development chamber (Twin through chamber $10 \mathrm{X} 10 \mathrm{~cm}$ with SS lid) and visualized under $254 \mathrm{~nm}$, visible light. After derivatization, the plates were again visualized at $254 \mathrm{~nm}, 366 \mathrm{~nm}$ and under visible light for all the extracts. After development, plates were sprayed with $5 \%$ methanolic sulphuric acid followed by heating at $105^{\circ} \mathrm{C}$ for $5-10 \mathrm{~min}$.

\section{HIV-Reverse transcriptase assay}

The effect of the methanolic extracts of the leaves, root bark and fruit pulp of A. digitata was tested by using non-radioactive HIVRT colorimetric ELISA kit (Roche Diagnostics, Germany). The protocol outlined in the kit was followed, under nuclease free conditions by using $2 \mathrm{ng}$ of the enzyme in each well and incubating the reaction for $2 \mathrm{~h}$ at $37^{\circ} \mathrm{C}$. The negative controls for the assay included HIV-1 RT with only lysis buffer, HIV-1 RT with only solvent (2\% DMSO) in lysis buffer. The blank consisted only 2,2'azino-bis (3-ethylbenzo-thiazoline-6-sulphonic acid) abbreviated as ABTS.

The positive control used was nevirapine (Aspen Pharmacare, South Africa), which is one of the most common reverse transcriptase inhibitors used in clinical practice. The HIV-RT inhibition of methanolic extracts was measured as a percentage of the inhibition that occurred with HIV-1 RT in the presence of no inhibitor in the same solvent (2\% DMSO) as the extracts.

\section{HIV-protease assay}

The HIV-1 PR assay was performed by using a fluorogenic octapeptide substrate, HIV-FRET (1) (Fluorescent resonance energy transfer) and a recombinant HIV-1 protease solution (Ana Spec Inc., USA). The peptide sequence of HIV-1 FRET (1) is derived from a natural processing site for HIV-1 PR and its structure is reported as: 4-(4-dimethylaminophenylazo)-benzoic acid (DABCYL)-Ser-GlnAsn-Tyr-Pro-Ile-Val-Gln-5-[(2-aminoethyl) amino] naphthalene-1 sulfonic acid (EDANS)]. The procedure for the continuous fluorogenic detection of HIV-1 PR was adopted from the method reported by Matayoshi et al. [31]. The fluorogenic substrate was dissolved in DMSO to $1.3 \mathrm{mM}$. The stock recombinant HIV-1 protease solution of $200 \mathrm{ng} / \mu \mathrm{l}$ was diluted to the concentration of $75 \mathrm{ng} / 45 \mu \mathrm{l}$ of freshly prepared assay buffer $(100 \mathrm{mM}$ sodium acetate, $1 \mathrm{M}$ sodium chloride, $1 \mathrm{mg} / \mathrm{ml} \mathrm{BSA}, 1 \mathrm{mM}$ EDTA and $1 \mathrm{mM}$ dithiothreitol, $\mathrm{pH}$ 4.7). To the wells of a 96-well black microtiter plate, $45 \mu \mathrm{l}$ of diluted HIV-1 PR (adjusted to a final concentration of $75 \mathrm{ng} /$ well) and $5 \mu \mathrm{l}$ of methanolic extract or control were added and incubated at $37^{\circ} \mathrm{C}$ for $15 \mathrm{~min}$. During this incubation process, the stock substrate was diluted to $16 \mathrm{M}$ by assay buffer and preheated to $37^{\circ} \mathrm{C}$. The diluted substrate $(50 \mu \mathrm{l})$ was added, to initiate the reaction of substrate cleavage by HIV-1 PR.

The microplates were then shaken to $300 \mathrm{rpm}$ for $1 \mathrm{~min}$. and the fluorescence intensity was measured kinetically every $30 \mathrm{sec}$ over a period of $100 \mathrm{~min}$. at an excitation wavelength of $355 \mathrm{~nm}$ and an emission wavelength of $460 \mathrm{~nm}$, at $37^{\circ} \mathrm{C}$, using a Fluoroskan Ascent FL microplate reader (Thermolab systems). The reaction rates were determined by the gradient of the initial linear portions (first 5-10 $\mathrm{min}$ ) of the plot of Relative fluorescence intensity (RFI) as a function of time. Negative controls were HIV-1 PR with only assay buffer, HIV-1 PR enzyme with DMSO (2\%) in assay buffer and substrate alone. Positive controls were taken as ritonavir and pepstatin at a final concentration of $0.2 \mu \mathrm{M}$ (Bachem, Switzerland). The percentage inhibition of HIV-1 PR was calculated as a percentage of control with only solvent ( $2 \%$ DMSO).

\section{RESULTS}

\section{Extractive values and preliminary phytochemical screening}

The leaves (ASLE), root bark (ASBE), fruit pulp (FPE) of A. digitata afforded methanolic extract in the percent yield of $3 \%, 2.3 \%$ and $1.4 \%$ respectively. Preliminary phytochemical screening of all the extracts revealed the presence of flavonoids, steroids, tannins, glycosides and amino acids.

\section{High performance thin layer chromatography}

High performance thin layer chromatographic study of the methanolic extract of leaf (ASLE) in the solvent system, toluene: ethyl acetate: diethyl amine (7:3:0.5) revealed five spots with $\mathrm{Rf}$ values 0.10 (yellow), 0.64 (yellowish green), 0.82 (black), 0.84 (green) and 0.90 (green) when observed under visible light while fruit pulp extract (FPE) in the same solvent system showed four spots with Rf value 0.34 (light blue), 0.64 (faint), 0.71 (light blue), 0.84 (blue) when observed at $366 \mathrm{~nm}$. Methanolic extract of the bark (ASBE) in the solvent system, toluene: ethyl acetate (9:1) revealed one major and seven minor spots with Rf values 0.12 (white), 0.16 (red), 0.26 (sky blue), 0.28 (red), 0.37 (blue), 0.50 (red), 0.60 (blue), 0.66 (red) when observed at $366 \mathrm{~nm}$ as reported by Sharma and Rangari [32].

\section{HIV-Reverse transcriptase assay}

The percentage inhibition of controls and A. digitata leaves, root bark and fruit pulp extracts were calculated relative to uninhibited HIV-1 RT in 2\% DMSO (fig. 1). The results of the HIV-1 RT assay indicated $26.5 \%$ inhibition by root bark extract $(50 \mu \mathrm{g} / \mathrm{ml})$ and $12.2 \%$ inhibition by leaf extract $(50 \mu \mathrm{g} / \mathrm{ml})$ while the fruit pulp extract $(100 \mu \mathrm{g} / \mathrm{ml})$ has shown only $5.9 \%$ inhibition as compared to standard nevirapine (100 nM) $27.5 \%$ inhibition.

\section{HIV-protease assay}

The percentage inhibition of controls and A. digitata leaves, root bark and fruit pulp extracts were calculated relative to uninhibited HIV-1 PR in 2\% DMSO (fig. 2). The leaf and fruit pulp extract (50 $\mu \mathrm{g} / \mathrm{ml}$ ) have shown quite high inhibition ( $\geq 50 \%$ ) to the extent of $75 \%$ and $74 \%$ respectively which is very significant. Since BSA was already present in the protease assay buffer at $0.1 \%$, tannin adsorption would already have taken place. 


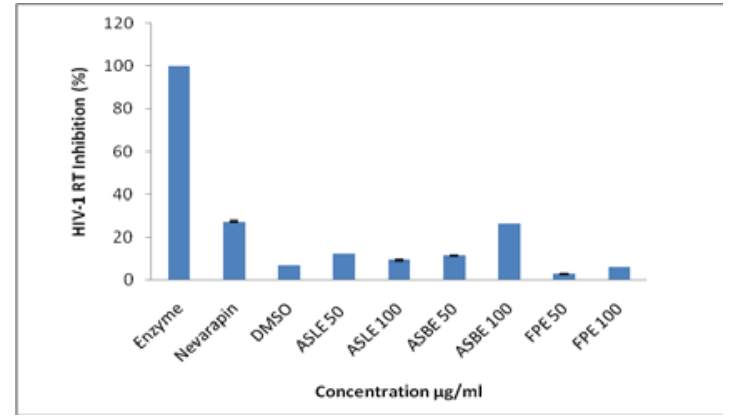

Fig. 1: HIV-1 RT inhibition by leaves, root bark and fruit pulp extract of $A$. digitata. Data are expressed as means \pm SEM of at least three independent measurements. The RT inhibition of all methanolic extracts are the mean of three separate experiments

ASLE: A. digitata leaves extract, ASBE: A. digitata root bark extract, FPE: A. digitata fruit pulp extract.

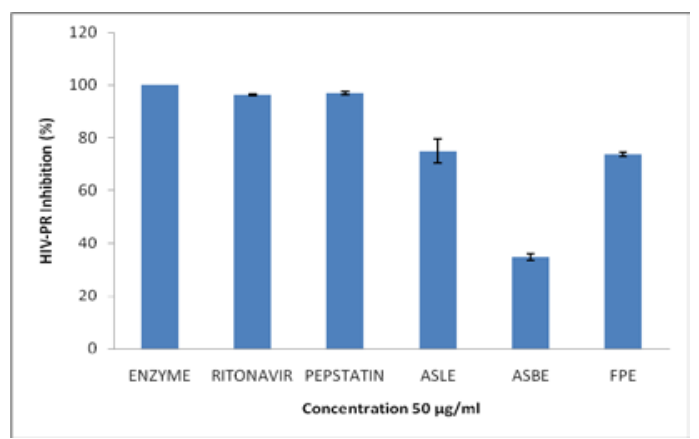

Fig. 2: HIV-1 PR inhibition by leaves, root bark and fruit pulp extract of $A$. digitata. Data are expressed as means \pm SEM of at least three independent measurements. The PR inhibition of all methanolic extracts are the mean of three separate experiments

ASLE: A. digitata leaves extract, ASBE: A. digitata root bark extract, FPE: A. digitata fruit pulp extract.

\section{DISCUSSION}

The results depicted in fig. 1, showed the significant inhibition of HIV-1 RT by the root bark extract while the leaf and fruit pulp extract showed very less inhibition. This significant inhibition of HIV1 RT by root bark extract seems to be due to the presence of various flavonoid glycosides reported from the roots of $A$. digitata L [21, 3334]. This HIV-1 RT inhibitory effect of such flavonoids has also reported in Chamaesyce hyssopfolia [35] and Vitex negundo L [36]

The leaves and fruit pulp extract showed the significant HIV-1 PR inhibition (75\% and $74 \%$ respectively) as indicated in fig. 2 . We would like to mention here that the results obtained in the cases of leaves and fruit pulp extracts does not seem to be reliable due to high background fluorescence. However, these significant results can be ascribed to the presence of the various proanthocyanidin compound reported in the leaves and the epicatechin compounds reported from the fruit pulp of A. digitata [37]. Such potential HIV-1 PR inhibitory activities have been reported in a number of structurally similar flavonoids and tannins [38-40].

\section{CONCLUSION}

The results obtained from this experimental work indicated that the flavonoids, proanthocynins and catechins present in the root bark, leaves and fruit pulp extracts of $A$. digitata have very strong potential to inhibit HIV-1 RT and PR enzymes. Further phytochemical and anti-HIV activity studies may provide important leads from A. digitata for the development of anti-HIV agent.

\section{ACKNOWLEDGEMENT}

The authors acknowledge with thanks the help of Prof. M. Van De Venter and Dr. Janine Mackenzie, Department of Biochemistry and Microbiology, Nelson Mandela Metropolitan University, Port Elizabeth, South Africa, for the HIV enzyme inhibitory activity against HIV-1.

\section{CONFLICTS OF INTERESTS}

Declared none

\section{REFERENCES}

1. UNAIDS India. Report on the Global AIDS epidemic 2010. Available from: http://www.unaids.org. [Last accessed on 20 Mar 2016].

2. Fletcher CV, Kakuda TN, Collier AC, Talbert RL, Yee GC, Matzke GR, et al. Pharmacotherapy-a pathophysiologic approach. 5th edition. Mcgraw-Hill: 2002. Medical Publishing Division, United States of America; 2002. p. 2151-74.

3. Cos P, Maes L, Vanden Berghe D, Hermans N, Pieters L, Vlietinck A. Plant substances as anti-HIV agents selected according to their putative mechanism of action. J Nat Prod 2004;67:284-93.

4. Mandal D, Jana S, Bhattacharya SK, Chakrabarti S. HIV type 1 subtypes circulating in eastern and northeastern regions of India. AIDS Res Hum Retroviruses 2002;18:1219-27.

5. National AIDS Control Organization (NACO). National AIDS Control Organisation 2006. Available from http:// www.nacoonline.org. [Last accessed on 20 Mar 2016].

6. De Clercq E. Current lead natural products for the chemotherapy of human immunodeficiency virus (HIV) infection. Med Res Rev 2000;20:323-49.

7. Cos P, Vanden Berghe D, Bruyne TD, Vlietinck A. Plant substances as anti-viral agents: an update (1997-2001). Curr Org Chem 2004;7:1163-80.

8. Harnett SM, Oosthuizen V, van de Venter M. Anti-HIV activities of organic and aqueous extracts of Sutherlandia frutescens and Lobostemon trigonus. J Ethnopharmcol 2005;96:113-9.

9. Zhang $\mathrm{K}$, Wang J, Jiang $\mathrm{Y}, \mathrm{Xu}$ LZ. Utilization of traditional Chinese medicines in the treatment of 200 people living with HIV/AIDS. Chin J AIDS STD 2005;11:94-6.

10. Asres K, Bucar F, Kartnig T, Witvrouw M, Pannecouque C, De Clercq E. Antiviral activity against human immunodeficiency virus type 1 (HIV-1) and type 2 (HIV-2) of ethnobotanically selected ethiopian medicinal plants. Phytother Res 2001;15:62-9.

11. Vermani K, Garg S. Herbal medicines for sexually transmitted diseases and AIDS. J Ethnopharmacol 2002;80:49-66.

12. Farnsworth NR. Ethnopharmacology and drug development. Ethnobotany, drug development and biodiversity conservationexploring the linkages. In: Ethnobotany and the Search for New Drugs; Ciba Foundation Symposium. John Wiley and Sons, Chichester; 1995;185:42-59.

13. Fabricant DS, Farnsworth NR. The value of plants used in traditional medicine for drug discovery. Environ Health Perspect 2001;109:69-75.

14. Wang JH, Tam SC, Huang H, Ouyang DY, Wang YY, Zheng YT. Site-directed PEGylation of trichosanthin retained its anti-HIV activity with reduces potency in vitro. Biochem Biophys Res Commun 2004a;317:965-71.

15. Ng TB, Huang B, Fong WP, Yeung HW. Anti-human immunodeficiency virus (anti-HIV) natural products with special emphasis on HIV reverse transcriptase inhibitors. Life Sci 1997;61:933-49.

16. Vlietinck AJ, De Bruyne T, Apers S, Pieters LA. Plant-derived leading compounds for chemotherapy of human immunodeficiency virus (HIV) infection. Planta Med 1998;64:97-109.

17. Yang SS, Gragg GM, Newman DJ, Bader JP. Natural product based anti-HIV drug discovery and development facilitated by the NCI developmental therapeutics program. J Nat Prod 2001;64:265-77.

18. Rangari VD, Dumbre RK, Dumbre MR. HIV-AIDS and bioactive natural products. Studium Press Llc, Houston, Texas, USA; 2009. 
19. Nadkarni KM, Nadkarni AK. Indian Materia Medica-2. $3^{\text {rd }}$ ed. Popular Prakasan, Bombay; 2000. p. 37-9.

20. Ramadan A, Harraz FM, El-Mougy SA. Anti-inflammatory, analgesic and antipyretic effects of the fruit pulp of Adansonia digitata. Fitoterapia 1994;LXV:418-22.

21. Shukla YN, Dubey S, Jain SP, Kumar S. Chemistry, biology and uses of Adansonia digitata-a review. J Med Aromat Plant Sci 2001;23:429-34.

22. Ramesh D, Dennis TJ, Shingare MS. Constituents of Adansoia digitata root bark. Fitoterapia 1992;63:278-9.

23. Van wyk BE, Gericke N. People's Plants: a guide to useful plants of Southern Africa. Pretoria, Briza Publication; 2000. p. 351

24. Esterhuyse N, Von Breitenbach J, Suhnge H. Remarkable trees of South Africa. Pretoria, Briza Publication; 2001.

25. Wickens GE. The Baobab-Africa's upside-down tree. Kew Bull 1982;37:173-209.

26. Van wyk BE, Van Heerden F, Van Oudtshoorn B. Poisonous plants of South Africa. Pretoria, Briza Publication; 2002. p. 288.

27. Hudson JB, Anani K, Lee MX, De Souzâ C, Arnason JT, Gbeassor $M$. Further investigations on the antiviral activities of medicinal plants of Togo. Pharm Biol 2000;38:46-50.

28. Atawodi SE, Bulus T, Ibrahim S, Amed DA, Nok AJ, Mamman M, Galadima M. In vitro trypanocidal effect of methanolic extract of some Nigerian savannah plants. Afr J Biotechnol 2003;2:317-21.

29. Kamatou GPP, Vermaak I, Viljoen AM. An updated review of Adansonia digitata: a commercially important African tree. S Afr J Bot 2011;77:908-19.

30. Anani K, Hudson JB, de Souzal C, Akpaganal K, Tower GHN, Amason, et al. Investigation of medicinal plants of Togo for antiviral and antimicrobial activities. Pharm Biol 2000;38:40-5.

31. Matayoshi ED, Wang GT, Krafft GA, Erickson J. Novel fluorogenic substrates for assaying retroviral proteases by resonance energy transfer. Science 1990;247:954-8.
32. Sharma A, Rangari VD. Antibacterial, the antifungal and antitubercular activity of methanolic extracts of Adansonia digitata. Int J Pharm Biol Sci 2015;10:52-60.

33. Chauhan JS, Chaturvedi R, Kumar S. A new Flavonol; I glycoside from the roots of Adansonia digitata. Planta Med 1984;50:113.

34. Chauhan JS, Kumar S, Chaturvedi R. A new flavonone glycoside from the roots of Adansonia digitata. Natl Acad Sci Lett 1987;10:177-9.

35. Yasmina A Lim, Ma Chao Mei, Ines $\mathrm{T}$ Kusumoto, Miyashiro $\mathrm{H}$ Hattori M. HIV-1 Reverse transcriptase inhibitory principles from Chamaesyce hyssopifolia. J Phytother Res 1997;11:22-7.

36. Kannan M, Rajendran P, Vedha V, Ashok G, Anushka S, Chandran, et al. HIV-1 reverse transcriptase inhibition by Vitex negundo L. leaf extract and quantification of flavonoids in relation to the anti-HIV activity. J Cell Mol Biol 2012;10:53-9.

37. Shahat AA. Procyanidins from Adansonia digitata. Pharm Biol 2006; 44:445-50.

38. Chaomei MA, Nakamura N, Miyashiro H, Hattori M, Shimotohno K. Inhibitory effect of constituents from Cynomorium songaricum and related triterpene derivatives on HIV-1 Protease. Chem Pharm Bull 1999;47:141-5.

39. Hong-XI XU, Wan $\mathrm{M}$, Dong $\mathrm{H}$, But PPH, Foo LY. Inhibitory activity of flavonoids and tannins against HIV-1 protease. Biol Pharm Bull 2000;23:1072-6.

40. Vlietinck AJ, Bruyne De T, Apers S, Pieters LA. Plant-derived leading compounds for chemotherapy of human immunodeficiency virus (HIV) infection. Planta Med 1998;64:97-109.

\section{How to cite this article}

- Amrish Sharma, Vinod Rangari. HIV-1 reverse transcriptase and protease assay of methanolic extracts of Adansonia digitata L. Int J Pharm Pharm Sci 2016;8(9):124-127. 